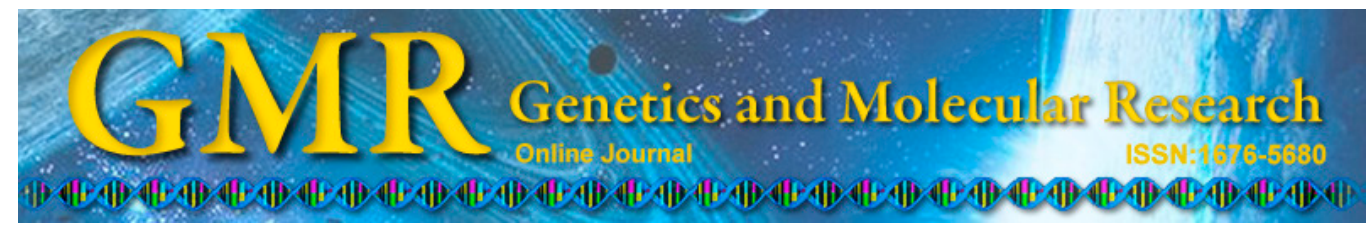

\title{
Polymorphisms in the PPAR $\gamma$ gene and their association with metabolic syndrome in Uyghurs and Kazakhs from Xinjiang, China
}

J. Chen, R.L. Ma, H. Guo, Y.S. Ding, J.Y. Zhang, J.M. Liu, M. Kerm, M. Zhang, S.Z. Xu, S.G. Li and S.X. Guo

Department of Preventive Medicine, Medical College of Shihezi University, Xinjiang, China

Corresponding author: S.X. Guo

E-mail: pge888@sina.com

Genet. Mol. Res. 14 (2): 6279-6288 (2015)

Received August 21, 2014

Accepted March 16, 2015

Published June 11, 2015

DOI http://dx.doi.org/10.4238/2015.June.11.1

\begin{abstract}
We investigated the association between polymorphisms rs 1801282 and rs3856806 of the PPAR $\gamma$ gene and metabolic syndrome (MS) among Uyghurs and Kazakhs. Mass spectrometry techniques were used to detect the PPAR $\gamma$ genotypes rs 1801282 and rs3856806 in 987 subjects, CC genotype and C allele frequencies were 83.6 and $91.7 \%$, respectively, at rs 1801282 in Kazakhs, which were higher than those in Uyghurs (72.3 and 85.0\%, respectively; $\mathrm{P}<0.05$ ). CC genotype and $\mathrm{C}$ allele frequencies were 73.6 and $85.3 \%$, respectively, at the rs 3856806 loci in Kazakhs, which were higher than those in Uyghurs (60.7 and $77.9 \%$, respectively; $\mathrm{P}<0.05$ ). For the rs3856806 polymorphism in Kazakhs, CT/TT genotype and T allele frequencies were 21.2 and $12.4 \%$ for MS subjects, which were lower than those for the control group (31.6 and $17.0 \%$, respectively; $\mathrm{P}<0.05$ ). Risk analysis of Kazakhs revealed that individuals with the CT and TT genotypes at rs3856806 had an increased risk, 0.524- and 0.770-fold, respectively, of developing MS than those possessing the $\mathrm{CC}$ genotype. Individuals with the $\mathrm{T}$ allele also had an increase in risk, by 0.699-fold, of developing MS than those with the C allele. For Uyghurs, those with the CC genotype at rs 1801282 had higher systolic blood pressure than those with the CG/GG genotype.
\end{abstract}


Among Kazakhs, those with the CC genotype at rs3856806 had higher triglyceride and waist-hip ratio levels but lower high-density lipoprotein cholesterol levels than those with the CT/TT genotype. The rs1801282 and rs3856806 PPAR $\gamma$ polymorphisms differ between Uyghurs and Kazakhs from Xinjiang Province, China.

Key words: Uyghur; Kazakh; Metabolic syndrome; PPAR $\gamma$; Gene polymorphism

\section{INTRODUCTION}

Metabolic syndrome (MS) is a cluster of conditions that severely affect the health of human individuals. It is characterized by insulin resistance, but can be diagnosed by the co-occurrence of various metabolic diseases, such as diabetes, impaired glucose regulation, hypertension, dyslipidemia, or central obesity (Bjorntorp, 1992; Kobayashi et al., 2011). As the standard of living has improved across populations, MS has become a global public health problem resulting in death and disability. The prevalence of MS is reported to be between 20 and 25\% (Sun et al., 2012). Among Kazakhs, the prevalence of MS is 26.6\% (Guo et al., 2011), while that in Uyghurs is $21.2 \%$ (Li et al., 2012). The prevalence of MS among these two nationalities is significantly higher than that in adults $35-74$ years old $(16.5 \%)$, across eight cities and provinces in mainland China (Gu et al., 2005).

It is generally accepted that MS is a complex disease caused by genetic, environmental, and other unknown factors (Pousada et al., 2006; Zhang et al., 2014). Common environmental factors include a high fat diet, reduced participation in sporting activities, and a generally unhealthy lifestyle. Genetic susceptibility is also a major cause of MS. Recent reports have shown a correlation between polymorphisms in peroxisome proliferator activated receptor $\gamma(\operatorname{PPAR} \gamma)$ and components of MS, such as hypertension, diabetes and obesity; however, the conclusions from these studies are inconsistent (Tellechea et al., 2009; Huguenin and Rosa, 2010; Bego et al., 2011). Whether polymorphisms at multiple loci of the PPAR $\gamma$ gene are related to the occurrence of MS in Uyghurs and Kazakhs remains unclear. Investigations into this issue are required to clarify the key risk factors of MS in Uyghurs and Kazakhs. We used a case-control study to investigate the association between mutations in the PPAR $\gamma$ gene and MS among Uyghurs and Kazakhs from Xinjiang Province, China.

\section{MATERIAL AND METHODS}

\section{Study population}

This study was conducted from 2009 to 2010, with stratified cluster sampling used for the investigation of MS status among research subjects. We included 3049 subjects who were Uyghurs (Jiangbazi, Jiashi County, Kashgar Prefecture) and 5692 subjects who were Kazakhs (Xinyuan County, Yili Prefecture); all subjects were from the Xinjiang Autonomous Region of mainland China. The age of the subjects was 18 years or more. According to the definition of MS proposed by the International Diabetes Federation in 2005 (Alberti et al., 2005), 250 Uyghur patients with MS were randomly selected (case group), along with 248 randomly selected cases of non-MS patients (control group). Similarly, 245 Kazakh patients with MS were 
randomly selected (case group), along with 244 cases of non-MS patients randomly selected using a group-matching method from the same population as the control group.

All selected subjects were given a questionnaire to survey demographic data, personal medical history, diet, and exercise. Laboratory tests were conducted to measure levels of fasting triglycerides (TG), low-density lipoprotein cholesterol (LDL-C), serum total cholesterol (TC), high-density lipoprotein cholesterol (HDL-C), and fasting plasma glucose (FPG). These tests were conducted on an automatic biochemical analyzer (Olympus AU400).

This study was conducted in accordance with the Declaration of Helsinki, with the approval of the Ethics Committee of Medical College of Shihezi University. All participants signed informed consent forms.

\section{DNA extraction}

Fasting venous blood $(200 \mu \mathrm{L})$ was obtained from subjects, and a blood genomic DNA isolation kit (Spin Column; BioTeke, Beijing, China) was used to extract genomic DNA from whole blood. All extracted DNA was verified by $0.7 \%$ agarose $(\mathrm{w} / \mathrm{v})$ gel electrophoresis. A NanoDrop (NanoDrop Technologies, Inc, Wilmington, DE, USA) spectrophotometer was used to quantify the concentration and purity of DNA. The optical density (OD) at 260 $\mathrm{nm}\left(\mathrm{OD}_{260}\right)$ and $280 \mathrm{~nm}\left(\mathrm{OD}_{280}\right)$ of samples was measured and the $\mathrm{OD}_{260 / 280}$ ratio determined. Samples with an $\mathrm{OD}_{260 / 280}$ ratio of 1.7-2.0 and concentration greater than or equal to $30 \mathrm{ng} / \mu \mathrm{L}$ were used. The DNA samples that met these criteria were diluted in double-distilled water to adjust the concentration to $10-30 \mathrm{ng} / \mu \mathrm{L}$ and stored at $-80^{\circ} \mathrm{C}$.

\section{Matrix-assisted laser desorption/ionization time-of-flight mass spectrometry (MALDI-TOF-MS)}

\section{Polymerase chain reaction (PCR) assays}

Oligonucleotide primers were designed using the MySequenom website (https:// www.mysequenom.com/Home) and Assay Designer 3.0. All PCRs were conducted in a 5- $\mu \mathrm{L}$ volume and the reaction mixture comprised $0.1 \mu \mathrm{L}$ dNTPs, $0.7 \mu \mathrm{L}$ DNA, $0.15 \mu \mathrm{L}$ Taq DNA polymerase, $1.35 \mu \mathrm{L}$ water, $0.4 \mu \mathrm{L} \mathrm{MgCl}_{2}, 0.5 \mu \mathrm{L} 10 \mathrm{X}$ PCR buffer, and $1.8 \mu \mathrm{L}$ primer mixture. Thermal cycling conditions involved an initial denaturation step at $94^{\circ} \mathrm{C}$ for $4 \mathrm{~min}$, followed by 45 amplification cycles $\left(94^{\circ} \mathrm{C}\right.$ for $20 \mathrm{~s}, 56^{\circ} \mathrm{C}$ for $30 \mathrm{~s}$, and $72^{\circ} \mathrm{C}$ for $1 \mathrm{~min}$ ), and a final extension step at $72^{\circ} \mathrm{C}$ for 3 min. Reactions were then incubated at $4^{\circ} \mathrm{C}$. All reactions were conducted in a thermal cycler in conjunction with parallel negative controls.

\section{Purification of amplicons}

Shrimp alkaline phosphatase (SAP) was used to remove dNTP overhangs from PCR amplicons. The final volume of each SAP reaction was $2.0 \mu \mathrm{L}$ and comprised $0.17 \mu \mathrm{L} 10 \mathrm{X}$ SAP buffer, $1.53 \mu \mathrm{L}$ double-distilled water, and $0.3 \mu \mathrm{L}$ SAP. Reactions were incubated at $37^{\circ} \mathrm{C}$ for $40 \mathrm{~min}$ and then at $85^{\circ} \mathrm{C}$ for $5 \mathrm{~min}$ before storage at $4^{\circ} \mathrm{C}$.

\section{Single-base extension}

The final volume of single-base extension reactions was $2.0 \mu \mathrm{L}$ and comprised $0.2 \mu \mathrm{L}$ 
5X iPlex Buffer, $0.94 \mu \mathrm{L}$ primer mix, $0.2 \mu \mathrm{L}$ iPlex terminator, $0.619 \mu \mathrm{L}$ water, and $0.041 \mu \mathrm{L}$ iPlex enzymes. Reactions were incubated at $94^{\circ} \mathrm{C}$ for $30 \mathrm{~s} ; 40$ cycles of $94^{\circ} \mathrm{C}$ for $5 \mathrm{~s}, 52^{\circ} \mathrm{C}$ for $5 \mathrm{~s}$ and $80^{\circ} \mathrm{C}$ for $1 \mathrm{~min}$; five cycles of $52^{\circ} \mathrm{C}$ for $5 \mathrm{~s}$; and $80^{\circ} \mathrm{C}$ for $1 \mathrm{~min}$. Finally, reactions were subject to extension at $72^{\circ} \mathrm{C}$ for $3 \mathrm{~min}$ and stored at $4^{\circ} \mathrm{C}$.

\section{MALDI-TOF-MS analysis}

After samples were purified using resin, a MassARRAY Nanod-ispenser (Sequenom, San Diego, CA, USA) was used to transfer the purified products to a SpectroCHIP (Sequenom) chip and MALDI-TOF-MS was used for analysis. We used TYPER 4.0 (Sequenom) to complete the classification and obtain the results.

\section{Statistical analysis}

Epidata 3.02 was used to establish a database, and a double entry method was used for data entry and logical error detection. To confirm the group representation of the sample, we used the Hardy-Weinberg equilibrium. SPSS17.0 was used for statistical analysis. A gene counting method was used to calculate the genotype and allele frequencies. For comparison between groups, the chi-square test was used. To compare clinical variables between groups, the Student $t$-test was used. Logistic regression analysis was used for risk factors. Odds ratio (OR) and 95\% confidence interval (CI) were calculated.

\section{RESULTS}

\section{Clinical characteristics}

General clinical data for subjects in the MS and control groups are shown (Table 1), with no significant difference observed for gender and age between Uyghurs and Kazakhs $(\mathrm{P}>0.05)$.

\begin{tabular}{|c|c|c|c|c|}
\hline \multirow[t]{2}{*}{ Clinical and biochemical indexes } & \multicolumn{2}{|c|}{ Uyghur } & \multicolumn{2}{|c|}{ Kazakh } \\
\hline & MS group & Control group & MS group & Control group \\
\hline $\mathrm{N}$ (male/female) & $250(86 / 164)$ & $248(85 / 163)$ & $245(85 / 160)$ & $244(83 / 161)$ \\
\hline Age (year) & $41.34 \pm 13.39$ & $40.89 \pm 12.21$ & $42.51 \pm 9.61$ & $41.49 \pm 8.80$ \\
\hline Height $^{*}(\mathrm{~cm})$ & $159.00 \pm 8.15$ & $157.40 \pm 7.68^{*}$ & $163.58 \pm 8.10$ & $161.82 \pm 7.69^{*}$ \\
\hline Weight ${ }^{*}(\mathrm{~kg})$ & $64.36 \pm 11.69$ & $52.64 \pm 8.61 *$ & $74.30 \pm 13.47$ & $57.53 \pm 8.85^{*}$ \\
\hline $\mathrm{WC}(\mathrm{cm})$ & $92.88 \pm 8.96$ & $76.22 \pm 5.78^{*}$ & $93.87 \pm 9.35$ & $76.07 \pm 7.07 *$ \\
\hline $\mathrm{HC}^{\#}(\mathrm{~cm})$ & $99.46 \pm 7.65$ & $90.65 \pm 5.85^{*}$ & $102.32 \pm 6.70$ & $91.50 \pm 5.89^{*}$ \\
\hline TG (mM) & $1.77 \pm 0.93$ & $0.85 \pm 0.33 *$ & $1.76 \pm 1.57$ & $0.86 \pm 0.36^{*}$ \\
\hline TC (mM) & $4.75 \pm 1.11$ & $4.20 \pm 1.00 *$ & $4.69 \pm 1.10$ & $4.30 \pm 0.95^{*}$ \\
\hline LDL-C (mM) & $2.66 \pm 0.74$ & $2.23 \pm 0.69^{*}$ & $2.61 \pm 0.90$ & $2.16 \pm 0.61 *$ \\
\hline HDL-C (mM) & $1.09 \pm 0.25$ & $1.32 \pm 0.27 *$ & $1.27 \pm 0.40$ & $1.57 \pm 0.41 *$ \\
\hline $\mathrm{SBP}^{*}(\mathrm{mmHg})$ & $130.12 \pm 20.89$ & $112.14 \pm 11.2 *$ & $140.03 \pm 22.25$ & $123.40 \pm 19.3^{*}$ \\
\hline $\mathrm{DBP}^{\#}(\mathrm{mmHg})$ & $82.93 \pm 13.31$ & $70.65 \pm 9.38^{*}$ & $90.77 \pm 13.63$ & $79.37 \pm 11.41 *$ \\
\hline $\mathrm{FPG}^{\#}(\mathrm{mM})$ & $4.50 \pm 0.92$ & $4.30 \pm 0.55^{*}$ & $5.23 \pm 1.90$ & $4.54 \pm 0.81^{*}$ \\
\hline WHR & $0.93 \pm 0.06$ & $0.83 \pm 0.06^{*}$ & $0.92 \pm 0.07$ & $0.83 \pm 0.05^{*}$ \\
\hline $\mathrm{BMI}^{\#}\left(\mathrm{~kg} / \mathrm{m}^{2}\right)$ & $25.34 \pm 3.65$ & $21.18 \pm 2.64 *$ & $27.70 \pm 4.19$ & $21.91 \pm 2.58^{*}$ \\
\hline \multicolumn{5}{|c|}{$\begin{array}{l}\mathrm{MS}=\text { metabolic syndrome; } \mathrm{WC}=\text { waist circumference; } \mathrm{HC}=\text { hip circumference; } \mathrm{BMI}=\text { body mass index; } \mathrm{WHR}=\text { waist- } \\
\text { to-hip ratio; } \mathrm{SBP}=\text { systolic blood pressure; } \mathrm{DBP}=\text { diastolic blood pressure; } \mathrm{TC}=\text { total cholesterol; } \mathrm{TG}=\text { triglyceride; } \\
\mathrm{HDL}-\mathrm{C}=\text { high-density lipoprotein cholesterol; } \mathrm{LDL}-\mathrm{C}=\text { low-density lipoprotein cholesterol; } \mathrm{FPG}=\text { fasting plasma } \\
\text { glucose; MS group } v \text { s control group in the same nationality. }{ }^{*} \mathrm{P}<0.05 \text {; comparison of biochemical indicators between } \\
\text { Uyghurs and Kazakhs, }{ }^{\#} \mathrm{P}<0.05 \text {. }\end{array}$} \\
\hline
\end{tabular}


In the Uyghur and Kazakh MS groups, the results for a number of parameters were higher [height, weight, waist circumference, hip circumference (HC), TG, TC, LDL-C, systolic blood pressure (SBP), diastolic blood pressure (DBP), FPG, waist-hip ratio (WHR), and body mass index $(\mathrm{BMI})$ ] than those in controls $(\mathrm{P}<0.05)$. In addition, HDL-C levels in the Uyghur and Kazakh MS groups were lower compared with those in controls $(\mathrm{P}<0.05)$. In general, height, weight, $\mathrm{HC}$, SBP, DBP, FPG, and BMI were higher in Kazakhs than in Uyghurs $(\mathrm{P}<0.05)$.

\section{Hardy-Weinberg equilibrium test}

For the MS and control groups of Uyghurs and Kazakhs, genotype frequencies of the rs 1801282 and rs3856806 loci were in Hardy-Weinberg equilibrium $(\mathrm{P}>0.05)$. These results for the PPAR $\gamma$ gene in both nationalities indicated a genetic equilibrium with adequate representation of the population for subsequent analysis.

\section{Comparison of rs1801282 and rs3856806 polymorphisms}

The distribution frequencies of the rs1801282 CC genotype in Uyghurs and Kazakhs were 72.3 and $83.6 \%$, respectively. The distribution frequencies of the rs $1801282 \mathrm{CG} / \mathrm{GC}$ genotype in Uyghurs and Kazakhs were 27.7 and 16.4\%, respectively. The distribution frequencies of the $\mathrm{C}$ alleles in Uyghurs and Kazakhs were 85.0 and $91.7 \%$, respectively, while the distribution frequencies of the $\mathrm{G}$ alleles in Uyghurs and Kazakhs were 15.0 and 8.3\%, respectively. There were significant differences in distribution frequencies of the three genotypes and alleles of the rs 1801282 loci between Uyghurs $\left(\chi^{2}=18.477, \mathrm{P}=0.000\right)$ and Kazakhs $\left(\chi^{2}=21.423, \mathrm{P}=0.000\right)$.

Distribution frequencies of the rs3856806 CC genotype in Uyghurs and Kazakhs were 60.7 and $73.6 \%$, respectively. The distribution frequencies of the rs3856806 CT/TT genotype in Uyghurs and Kazakhs were 39.3 and 26.4\%, respectively. Distribution frequencies of C alleles were 77.9 and $85.3 \%$ for Uyghurs and Kazakhs, respectively. Distribution frequencies of $\mathrm{T}$ alleles were 22.1 and $14.7 \%$ for Uyghurs and Kazakhs, respectively. There were significant differences in the distribution frequencies of the three genotypes and alleles of the rs3856806 loci between Uyghurs $\left(\chi^{2}=18.510, P=0.000\right)$ and Kazakhs $\left(\chi^{2}=17.630\right.$, $\mathrm{P}=0.000)($ Table 2).

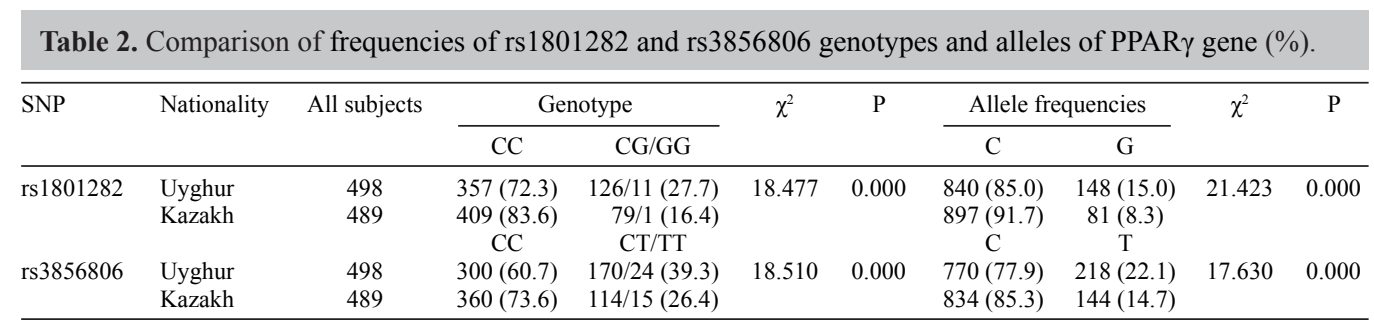

\section{Association between rs1801282 and rs3856806 polymorphisms of PPAR $\gamma$ and MS}

In Uyghurs, no significant difference was observed in the distribution frequencies of 
genotypes and alleles of the rs 1801282 and rs3856806 polymorphisms of PPAR $\gamma$ between the MS and control groups $(P>0.05)$. In Kazakhs, no significant difference was observed in the distribution frequencies of genotypes and alleles of the rs 1801282 polymorphism of PPAR $\gamma$ between MS and control groups $(\mathrm{P}>0.05)$. Frequencies of rs3856806 CT/TT genotypes and the $\mathrm{T}$ allele were lower in the MS group (21.2 and $12.4 \%$, respectively) than in controls ( 31.6 and $17.0 \%$, respectively); the differences were statistically significant (MS group: $\chi^{2}=9.353$, $\mathrm{P}=0.009$; control group: $\chi^{2}=4.048, \mathrm{P}=0.044$ ) (Tables 3 and 4).

Table 3. Comparison of frequencies of rs1801282 genotypes and alleles between MS groups and controls of Uyghurs and Kazakhs (\%).

\begin{tabular}{|c|c|c|c|c|c|c|c|c|c|c|}
\hline \multirow[t]{2}{*}{ Nationality } & \multirow[t]{2}{*}{ Group } & \multirow[t]{2}{*}{ All subject } & \multicolumn{2}{|c|}{ Genotype } & \multirow[t]{2}{*}{$\chi^{2}$} & \multirow[t]{2}{*}{$\mathrm{P}$} & \multicolumn{2}{|c|}{ Allele frequencies } & \multirow[t]{2}{*}{$\chi^{2}$} & \multirow[t]{2}{*}{$\mathrm{P}$} \\
\hline & & & $\mathrm{CC}$ & $\mathrm{CG} / \mathrm{GG}$ & & & $\mathrm{C}$ & G & & \\
\hline \multirow[t]{2}{*}{ Uyghur } & MS group & 250 & $179(72.2)$ & $67 / 2(27.8)$ & \multirow[t]{2}{*}{4.957} & \multirow[t]{2}{*}{0.084} & $425(85.7)$ & $71(14.3)$ & \multirow[t]{2}{*}{0.346} & \multirow[t]{2}{*}{0.556} \\
\hline & Control group & 248 & $178(72.8)$ & $59 / 9(27.2)$ & & & $415(84.3)$ & 77 (15.7) & & \\
\hline \multirow[t]{2}{*}{ Kazakh } & MS group & 245 & $204(73.1)$ & 40/1 (26.9) & \multirow[t]{2}{*}{1.399} & \multirow[t]{2}{*}{0.497} & $448(91.4)$ & $42(8.6)$ & \multirow[t]{2}{*}{0.108} & \multirow[t]{2}{*}{0.742} \\
\hline & Control group & 244 & $205(73.4)$ & $39 / 0(26.6)$ & & & $449(92.0)$ & $39(8.0)$ & & \\
\hline
\end{tabular}

\begin{tabular}{|c|c|c|c|c|c|c|c|c|c|c|}
\hline \multirow[t]{2}{*}{ Nationality } & \multirow[t]{2}{*}{ Group } & \multirow[t]{2}{*}{ All subject } & \multicolumn{2}{|c|}{ Genotype } & \multirow[t]{2}{*}{$\chi^{2}$} & \multirow[t]{2}{*}{$P$} & \multicolumn{2}{|c|}{ Allele frequencies } & \multirow[t]{2}{*}{$\chi^{2}$} & \multirow[t]{2}{*}{$P$} \\
\hline & & & $\mathrm{CC}$ & $\mathrm{CT} / \mathrm{TT}$ & & & $\mathrm{C}$ & $\mathrm{T}$ & & \\
\hline \multirow[t]{2}{*}{ Uyghur } & MS group & 250 & $150(60.5)$ & $90 / 8(39.5)$ & \multirow[t]{2}{*}{3.247} & \multirow[t]{2}{*}{0.197} & $390(78.6)$ & $106(21.4)$ & \multirow[t]{2}{*}{0.279} & \multirow[t]{2}{*}{0.597} \\
\hline & Control group & 248 & $150(61.0)$ & $80 / 16(39.0)$ & & & $380(77.2)$ & $112(22.8)$ & & \\
\hline \multirow[t]{2}{*}{ Kazakh } & MS group & 245 & $193(78.8)$ & $43 / 9(21.2)$ & \multirow[t]{2}{*}{9.353} & \multirow[t]{2}{*}{0.009} & $429(87.6)$ & $61(12.4)$ & \multirow[t]{2}{*}{4.048} & \multirow[t]{2}{*}{0.044} \\
\hline & Control group & 244 & $167(68.4)$ & 71/6 (31.6) & & & $405(83.0)$ & $83(17.0)$ & & \\
\hline
\end{tabular}

\section{Risk analysis of the PPAR $\gamma$ rs3856806 polymorphism and MS in Kazakhs}

Univariate logistic regression analysis of the PPAR $\gamma$ rs3856806 polymorphism in Kazakhs was conducted. Risk assessment was conducted with the $\mathrm{CC}$ genotype and $\mathrm{C}$ allele as controls, with $95 \% \mathrm{CIs}$ and ORs calculated. The risk of MS in individuals with rs3856806 CT and TT genotypes were 0.524 - and 0.770 -fold greater compared with those with the CC genotype. The risk of MS in individuals with the T allele was 0.699 -fold greater compared with those with the $\mathrm{C}$ allele (Table 5).

Table 5. Risk analysis of rs3856806 polymorphism of PPAR $\gamma$ gene in Kazakhs.

\begin{tabular}{|c|c|c|c|c|c|c|c|}
\hline \multirow[t]{2}{*}{ Nationality } & \multirow{2}{*}{$\frac{\text { Genotype }}{\text { Allele frequencies }}$} & \multirow{2}{*}{$\frac{\text { MS group }}{\mathrm{N}=245}$} & \multirow{2}{*}{$\frac{\text { Control group }}{\mathrm{N}=244}$} & \multirow[t]{2}{*}{$\chi^{2}$} & \multirow[t]{2}{*}{$\mathrm{P}$} & \multirow[t]{2}{*}{ OR } & \multirow[t]{2}{*}{$95 \% \mathrm{CI}$ for $\mathrm{OR}$} \\
\hline & & & & & & & \\
\hline \multirow[t]{5}{*}{ Kazakh } & $\mathrm{CC}$ & 193 & 167 & & & 1.000 & \\
\hline & CT & 43 & 71 & 8.747 & 0.003 & 0.524 & $0.340-0.807$ \\
\hline & TT & 9 & 6 & 0.237 & 0.627 & 0.770 & $0.269-2.210$ \\
\hline & $\mathrm{T}$ & 61 & 83 & 3.891 & 0.049 & 0.699 & $0.489-0.999$ \\
\hline & $\mathrm{C}$ & 426 & 405 & & & & \\
\hline
\end{tabular}




\section{Analysis of PPAR $\gamma$ polymorphisms and clinical biochemical indexes in Uyghurs and Kazakhs}

In Uyghurs, individuals with the rs1801282 CC genotype had higher SBP than those with the $\mathrm{CG} / \mathrm{GG}$ genotype $(\mathrm{P}<0.05)$. There was no significant difference observed between other indexes. In Kazakhs, no significant difference was noted in clinical biochemical indexes among the different genotypes at the rs1801282 locus. For Kazakhs, individuals with the rs3856806 CC genotype had higher TG and WHR than those with the CT/TT genotype (P $<0.05)$. Furthermore, Kazakh individuals with the rs3856806 CC genotype had lower HDL$\mathrm{C}$ levels than those with the CT/TT genotype $(\mathrm{P}<0.05)$, with no significant difference noted between other indexes. In Uyghurs, no significant difference was noted in clinical biochemical indexes between the different genotypes at the rs3856806 locus $(\mathrm{P}<0.05)$ (data not shown).

\section{DISCUSSION}

The PPARs are types of nuclear transcription factors activated by ligands and are members of the type II nuclear receptor superfamily (Meirhaeghe and Amouyel, 2004). The PPARs can be divided into three subtypes according to their biological structure: PPAR $\alpha$, PPAR $\beta$ (PPAR $\delta$ ), and PPAR $\gamma$ (Holness et al., 2009). PPAR $\gamma$ is by far the most widely studied PPAR subtype. It was first identified in 1990 on chromosome 3p-2-5 with an approximate length of $146 \mathrm{~kb}$ (Issemann and Greenbaum, 1990; Fajas et al., 1997). Because of different promoters and alternative splicing, four mRNA isomers can be produced, with nine exons. The rs1801282 locus is located at exon 2, while rs3856806 is located at exon 6 of the PPAR $\gamma$ gene. PPAR $\gamma$ is associated with nearly all components of MS, including diabetes and obesity (Kota et al., 2005), hyperlipidemia (Wahli and Michalik, 2012), atherosclerosis (Huang et al., 2012), and hypertension.

In the present study, we showed that there was no statistically significant difference between MS and control groups of Uyghurs and Kazakhs with respect to age or gender. Genotype frequency was also consistent with the Hardy-Weinberg equilibrium. Frequency distribution of single nucleotide polymorphisms varied among the different groups. We showed that $\mathrm{C}$ and $\mathrm{G}$ allele frequencies were 85.0 and $15.0 \%$, respectively, at the rs1801282 locus in Uyghurs. The rate of gene mutation was between 5.9 and $21.6 \%$ for Caucasians and higher than that in central Asian populations (1.7-9.3\%) (Gouda et al., 2010). Frequencies of the $\mathrm{C}$ and $\mathrm{T}$ alleles were 77.9 and $22.1 \%$, respectively, at the rs 3856806 locus. The allele mutation rate was similar to those previously reported in non-Asian races (Bego et al., 2011), but lower than that in the Chinese Han population (29.2\%) (Ding et al., 2012). C and G allele frequencies were 91.7 and 8.3\%, respectively, at the rs 1801282 locus in Kazakhs. The $\mathrm{C}$ and $\mathrm{T}$ allele frequencies were 85.3 and $14.7 \%$, respectively, at the rs 3856806 locus. We found that polymorphism distributions of rs 1801282 and rs3856806 were significantly different between Uyghurs and Kazakhs. The CG/GG genotype and G allele frequencies at the rs 1801282 locus, along with CT/TT genotype and T allele frequencies at the rs3856806 locus, in Uyghurs were all higher than those in Kazakhs. Our findings suggest that even though Uyghurs and Kazakhs live in close proximity in the Xinjiang region, distribution of PPAR $\gamma$ polymorphisms are influenced by different ethnic genetic factors.

Previous studies investigating the association between polymorphisms at the PPAR $\gamma$ locus and MS have resulted in inconsistent conclusions. Genotype and allele frequency dis- 
tributions at the rs1801282 and rs3856806 loci in the MS and control groups were not significantly different in Uyghurs. This suggests that polymorphisms at the two loci are not related to the occurrence of MS in Uyghurs. In Kazakhs, frequencies of the CT/TT genotype and T allele at the rs3856806 locus were lower compared with those in the control group. Following risk analysis on Kazakhs, individuals with the CT genotype at the rs3856806 locus had a 0.524-fold greater risk of developing MS than those with the CC genotype. Individuals with the $\mathrm{T}$ allele had 0.699 -fold greater risk of develop MS than those with the $\mathrm{C}$ allele. These results suggested that polymorphisms at the rs3856806 locus were associated with the occurrence of MS in Kazakhs, and the C allele was a risk factor for MS. In contrast, Tellechea et al. (2009) studied 572 Argentinean people and found that polymorphisms at the rs1801282 locus were associated with the incidence of MS. They also found that smoking increased the likelihood of developing MS. Huguenin and Rosa (2010) conducted a meta-analysis and found that rs 1801282 polymorphisms were associated with diabetes. The $\mathrm{G}$ allele can significantly reduce the incidence of diabetes among Caucasian populations. Haseeb et al. (2009) found that the rs1801282 and rs3856806 polymorphisms were not correlated to the development of MS in Indian populations. Cao et al. (2010) found that polymorphisms at the rs1801282 locus were not associated with the incidence of type 2 diabetes mellitus in Han Chinese from Jiangsu Province. Carriers of the rs3856806CT/TT genotype exhibited a lower risk of developing type 2 diabetes mellitus compared with CC genotype carriers. The different conclusions drawn from these previous studies could be due to different experimental designs, sample content, and differing ethnic and regional factors, highlighting that multi-ethnic and multi-area research studies should be performed.

We found that Uyghurs with the CC genotype at rs 1801282 had higher SBP than those with the CG/GG genotype. Among Kazakhs, people with the CC genotype at the rs 3856806 locus had higher TG and WHR but lower HDL-C levels than those with the CT/TT genotype. These results suggest that polymorphisms at rs 1801282 and $\mathrm{rs} 3856806$ could be related to hypertension in Uyghurs and to MS components such as blood lipids and obesity in Kazakhs. Gu et al. (2013) studied 820 people in Jiangsu Province and found that the rs1801282 CG/GG genotype might reduce the risk of hypertension $(\mathrm{OR}=0.70)$, and conferred beneficial effects with respect to the onset of hypertension. Ylihärsilä et al. (2004) found that hypertension patients with the rs1801282 C genotype tended to have higher SBP. It is possible that this genotype results in increased insulin resistance, thus activating the renin-angiotensin system and causing increased blood pressure. In coronary atherosclerotic heart disease patients, Zhou et al. (2012) found that the rs3856806 polymorphism was associated with higher HDL levels and lower blood glucose levels, leading to a decrease in the risk of chronic heart disease. Chehaibi et al. (2014) found that the $\mathrm{T}$ allele carriers had lower prevalence rates of diabetes mellitus and $\mathrm{TG}$ levels than $\mathrm{C}$ allele carriers $(\mathrm{OR}=0.575)$. These research results correspond to our findings; however, Passaro et al. (2011) could not discern an obvious correlation between PPAR $\gamma$ polymorphisms and MS.

The etiological mechanisms of MS are complicated and influenced by geography, racial differences, and other environmental factors. The role of other genes that are yet to be identified cannot be ruled out in MS etiology. We have examined the association between PPAR $\gamma$ polymorphisms and incidence of MS in Uyghurs and Kazakhs. We explored the possible pathogenesis of MS in these ethnic groups from a genetic perspective with the hope that our results could provide new insights for the diagnosis, prevention, and treatment of MS. 


\section{Conflicts of interest}

The authors declare no conflict of interest.

\section{ACKNOWLEDGMENTS}

Research supported by grants from the National Science and Technology Support Projects for the "Eleventh Five-Year Plan" of China (\#2009BAI82B04).

\section{REFERENCES}

Alberti KG, Zimmet P, Shaw J and IDF Epidemiology Task Force Consensus Group (2005). The metabolic syndrome-a new world-wide definition. Lancet 366: 1059-1062.

Bego T, Dujic T, Mlinar B, Semiz S, et al. (2011). Association of PPARG and LPIN1 gene polymorphisms with metabolic syndrome and type 2 diabetes. Med. Glas 8: 76-83.

Bjorntorp P (1992). Abdominal obesity and the metabolic syndrome. Ann. Med. 24: 465-468.

Cao YY, Ma JH and Li Q (2010). Association between genetic polymorphisms in exon 2 and 6 of the PPAR- $\gamma$ gene and susceptibility to T2DM in Han population of Jiangsu. Chin. J. Diabetes 18: 259-263.

Chehaibi K, Nouira S, Mahdouani K, Hamdi S, et al. (2014). Effect of the PPAR $\gamma$ C161T gene variant on serum lipids in ischemic stroke patients with and without type 2 diabetes mellitus. J. Mol. Neurosci. 54: 730-738.

Ding Y, Guo ZR, Wu M, Chen Q, et al. (2012). Effects of PPARD-87T > C and interactions with single nucleotide polymorphisms in PPARA and PPARG on abdominal obesity. Zhonghua Yi Xue Za Zhi 92: 1517-1521.

Fajas L, Raspe E, Schoonjans K, Lefebvre AM, et al. (1997). The organization, promoter analysis, and expression of the human PPARgamma gene. J. Biol. Chem. 272: 18779-18789.

Gouda HN, Sagoo GS, Harding AH, Yates J, et al. (2010). The association between the peroxisome proliferator-activated receptor-gamma2 (PPARG2) Pro12Ala gene variant and type 2 diabetes mellitus: a HuGE review and meta-analysis. Am. J. Epidemiol. 171: 645-655.

Gu DF, Reynolds K, Wu XG, Chen J, et al. (2005). Prevalence of the metabolic syndrome and overweight among adults in China. Lancet 365: 1398-1405.

Gu SJ, Guo ZR, Wu M, Ding Y, et al. (2013). Association of peroxisome proliferator-activated receptor $\gamma$ polymorphisms and haplotypes with essential hypertension. Genet. Test. Mol. Biomarkers 17: 418-423.

Guo H, Ma RL, Zhang JY, Rui DS, et al. (2011). Comparative analysis of epidemic characteristic of metabolic syndrome of Kazakh and Hans in Xinjiang. Chin. J. Hypertens. 19:538-543.

Haseeb A, Iliyas M and Chakrabarti S (2009). Single-nucleotide polymorphisms in peroxisome proliferator activated receptor $\gamma$ and their association with plasma levels of resistin and the metabolic syndrome in a South Indian population. J. Biosci. 34: 405-414.

Holness MJ, Samsuddin S and Sugden MC (2009). The role of PPARs in modulating cardiac metabolism in diabetes. Pharmacol. Res. 60: 185-194.

Huang JV, Greyson CR and Schwartz GG (2012). PPAR- $\gamma$ as a therapeutic target in cardiovascular disease: evidence and uncertainty. J. Lipid Res. 53: 1738-1754.

Huguenin GV and Rosa G (2010). The Ala allele in the PPAR-gamma2 gene is associated with reduced risk of type 2 diabetes mellitus in Caucasians and improved insulin sensitivity in overweight subjects. Br. J. Nutr. 104: 488-497.

Issemann I and Greenbaum S (1990). Activation of a member of the steroid hormone receptor superfamily by peroxisome proliferators. Nature 347: 645-650.

Kobayashi D, Takahashi T, Deshpande GA, Shimbo T, et al. (2011). Relation between metabolic syndrome and sleep duration in Japan: A large scale cross-sectional study. Intern. Med. 50: 103-107.

Kota BP, Huang TH and Roufogalis BD (2005). An overview on biological mechanisms of PPARs. Pharmacol. Res. 51: 85-94.

Li CH, Guo SX, Ma RL, Ding YS, et al. (2012). The epidemic situation of metabolic syndrome among the Uygur in Kashgar of Xinjiang in 2010. Chin. J. Prev. Med. 46: 419-423.

Meirhaeghe A and Amouyel P (2004). Impact of genetic variation of PPAR in humans. Mol. Genet. Metab. 83: 93-102.

Passaro A, Dalla Nora E, Marcello C, Di Vece F, et al. (2011). PPAR $\gamma$ Pro12Ala and ACE ID polymorphisms are associated with BMI and fat distribution, but not metabolic syndrome. Cardiovasc. Diabetol. 10: 112. 
Pousada JM, Britto MM, Cruz T, Lima ML et al. (2006). The metabolic syndrome in Spanish migrants to Brazil: unexpected results. Diabetes Res. Clin. Pract. 72: 75-80.

Sun K, Liu J and Ning G (2012). Active smoking and risk of metabolic syndrome: a meta-analysis of prospective studies. PLoS One 7: e47791.

Tellechea ML, Aranguren F, Pérez MS, Cerrone GE, et al. (2009). Pro12Ala polymorphism of the peroxisome proliferator activated receptor- $\gamma$ gene is associated with metabolic syndrome and surrogate measures of insulin resistance in healthy men. Circ. J. 73: 2118-2124.

Wahli W and Michalik L (2012). PPARs at the crossroads of lipid signaling and inflammation. Trends Endocrinol. Metab. 23: 351-363.

Ylihärsilä H, Eriksson JG, Forsén T, Laakso M, et al. (2004). Interactions between peroxisome proliferator-activated receptor-gamma 2 gene polymorphisms and size at birth on blood pressure and the use of antihypertensive medication. J. Hypertens. 22: 1283-1287.

Zhang Q, Zhang X, Zhao M, Huang H, et al. (2014). Correlation of obstructive sleep apnea hypopnea syndrome with metabolic syndrome in snorers. J. Biomed. Res. 28: 222-227.

Zhou X, Chen J and Xu W (2012). Association between C1431T polymorphism in peroxisome proliferator-activated receptor- $\gamma$ gene and coronary artery disease in Chinese Han population. Mol. Biol. Rep. 39: 1863-1868. 